\title{
Study on Innovation and Entrepreneurship Education Model of School-enterprise Cooperation of College Students
}

\author{
Yuzhong Sun \\ Chongqing City Management College, Chongqing 401331, China.
}

Keywords: college students, innovation and entrepreneurship, education model.

\begin{abstract}
School-enterprise Cooperation is the key point of innovation and entrepreneurship education for college students. The innovation and entrepreneurship education for college students needs enterprises to actively cooperate with the vocational colleges, and promote and practice innovative entrepreneurship education from the aspects of personnel training mode, talent quality standard, curriculum system construction, ability appraisal and campus culture.
\end{abstract}

\section{Introduction}

Innovation and entrepreneurship is the soul of national prosperity. To push"public entrepreneurship and innovation" is of great significance to promote the adjustment of the national economic structure, to build a new engine for development, to enhance the development of new impetus. The report of the 17th CPC National Congress clearly put forward the development strategy of" improving the capability of independent innovation, building an innovation-oriented country" and "to promote employment by promoting entrepreneurship". The 18th Party Congress has made important arrangements for the innovation and entrepreneurship talents. Innovation and entrepreneurship education in essence is the educational activities to stimulate the nature of people to create. ${ }^{[1]}$ The State Council has made clear requirements for strengthening innovation and entrepreneurship education. It is an important measure to promote the comprehensive reform of higher education and to promote the higher quality of college graduates. It is an important measure to promote the reform of higher education and improve the quality of higher education. Colleges and universities, which bear the task of cultivating innovative talents, gather a lot of outstanding young people, so they are undoubtedly the main body of innovation and entrepreneurship education. ${ }^{[2]}$ Colleges are the cradle of cultivating high-quality skilled talents. The school-enterprise cooperation system is the starting point for the cultivation of college's talents. Therefore, enterprises can not be vacant in innovation and entrepreneurship education in colleges.

\section{Main Modes of School-enterprise Cooperation Innovation and Entrepreneurship Education Colleges}

Jointly set up a creative and creative education steering committee. Higher vocational colleges actively introduce industry, enterprise professional and technical personnel to participate in the school innovation and entrepreneurship education, responsible for the consideration of innovative entrepreneurship education programs, professional training programs and teaching plans in the innovative business education module content to provide advice, guidance and help to students.

Innovation and entrepreneurship order class cooperation. Schools and enterprises sign innovation and entrepreneurship incubation training agreement. Some companies need high-volume innovation and entrepreneurship talents, such as Alibaba needs a lot of foreign trade enterprises to join the Alibaba global quick sell, such as chain companies need many franchisees, then these companies can cooperate with the school to cultivate innovative entrepreneurs, enterprises can 
provide business platform and practice for students, and hatch large quantities of future innovation and entrepreneurship talents.

Innovation and entrepreneurship teacher mutual appointment. The specific operation methods of are mainly that schools and enterprises under the premise of interest sharing sign agreement of employment of staff each other, provide of part-time jobs, training opportunities for each other. The school can introduce business personnel engaged in innovative entrepreneurship practice teaching to meet students for innovative business practice needs. At the same time school teachers can also practice in enterprises to enrich the entrepreneurial experience.

Cooperative enterprises accepting college students to get innovation and entrepreneurship practice. The internship cooperation means the enterprises according to the needs of the staff positions of the unit sign the agreement with the cooperative institutions and employ students to undertake specific job work. The students can get specific knowledge of entrepreneurial business content through the internship and business model for future business.

Running cooperative enterprises. Enterprises and schools and vocational students can run enterprise together according to the contents of innovative projects. Three parties put the funds, technology, venues, human resources, etc., to create a substantial operating-oriented enterprise. Enterprises are responsible for specific business guidance, incubation innovation enterprises. All parties work to achieve tripartite win.

\section{Practice content of school-enterprise cooperation innovation and entrepreneurship education mode for college students}

Perfecting the college talent education mechanism of innovation and entrepreneurship basing on school-enterprise cooperation. In the college talent education mechanism of innovation and entrepreneurship area, Colleges should carry out various forms of innovative business model practice in the concept of "combination of work and study" and "school-enterprise cooperation" and form "real environment" innovative entrepreneurship cooperative education mechanism which is closely connected with innovation and entrepreneurship needs and needs of economic and social development. As the cultivation of innovation and entrepreneurship ability requires comprehensive knowledge and ability as the basis, so the innovation and entrepreneurship mechanism of higher vocational education needs to break the barriers of each professional singles, and can explore the interdisciplinary courses in similar disciplines and professional groups. It needs to establish new cooperation mechanisms of cross-faculty, interdisciplinary, and cross-disciplinary training of innovation and entrepreneurship.

Formulate the college talent quality standard of innovation and entrepreneurship basing on school-enterprise cooperation. Higher vocational education is to cultivate high-quality skilled talents who meet the needs of needs of local enterprise development. Vocational colleges should meet the needs of enterprises. The innovation and entrepreneurship should be integrated into the professional training programs. The innovation and entrepreneurship education should be clearly embodied in the talent training schedules. The objectives of the ability and quality of innovation and entrepreneurship education should be refined. The spirit of innovation, entrepreneurial awareness and innovation and entrepreneurship ability should work as important indicators of the assessment of innovation and entrepreneurship quality. Accordingly innovation and entrepreneurship ability and quality standards should be made in line with the indicators.

Constructing a perfectly innovation and entrepreneurship education curriculum system basing on school-enterprise cooperation. Government, industry enterprises and vocational colleges should provide students with more real innovation and entrepreneurial practice platform. At present, the innovation and entrepreneurship education in higher vocational colleges is mainly an independent course, which is not effectively connected with the professional courses and can not be effectively combined with professional courses in the practice of specific innovation and entrepreneurship. Innovation and entrepreneurship education is a cross-system of multidisciplinary participation. ${ }^{[3]}$ Higher vocational innovation and entrepreneurship education needs to integrate with 
professional education, not only just arrange a specialized course in the professional talent training program, but integrate the concept and content into the professional talent training program. And the innovation and entrepreneurship education about the specialty needs to be treated as integral part of professional courses. Firstly, professional teachers need change their educational philosophy that professional teachers teach not only professional knowledge but also train the students to master the innovation and entrepreneurship knowledge and ability which can enable them to carry out innovation and entrepreneurship programs. Professional teachers need to dig into innovation and entrepreneurship education resources of the curriculum, such as the introduction of school-enterprise cooperation projects for students to provide innovative business practice platform, practice opportunities, such as guiding students to start a simulation or entrepreneurial combat basing on professional knowledge. Secondly, develop and perfect professional courses. On the basis of accurately grasping the connotation of innovation and entrepreneurship ability, we will further clarify the teaching ideas of the combination of innovation training and entrepreneurial ability promotion. Basing on the training of quality and the focus on thinking training, the innovation and entrepreneurship knowledge and ability needs to be covered as an important professional teaching materials or lectures content. The teachers need to develop sharing professional and innovative business education resources with experts from companies, and train the students with these materials so that students can form the professional innovation and entrepreneurship ideas, methods, patterns and practical impulses naturally during their learning. To develop these education resources which combines the professional knowledge and innovative entrepreneurship education ideas , the teachers needs to have practical innovation and entrepreneurship experiences, and also need to work closely with the industry experts to ensure the content of the actual combat, innovation and real operability.

Strengthening real practical innovation and entrepreneurship education of in higher vocational education. Government, industry enterprises and vocational colleges should provide students with more real innovation and entrepreneurship practice platform. The schools need to create innovative business practice base, college students Pioneering Park, business incubator base or small micro-business base, according to the professional categories of courses. And they also need to provide students with space, infrastructure which are equipped with professional teachers within the school, industry instructors. Even the schools need to introduce the cooperation companies and introduce professional platform and even products, through this to make college students start up enterprises. As to the management of the student innovation and entrepreneurship projects, they need to use the real enterprise implement management and project operation, to introduce real work into the task in the teaching. Through the actual practice, to make the students have effective innovation and entrepreneurship training experience and to stimulate students' innovative entrepreneurial potential, cultivate student's innovative entrepreneurial ability. For example, the school can cooperate with the relevant enterprises, so that enterprises provide foreign trade products for students to start trading companies. Students get orders after the profit, and then give the enterprise payment. This kind of cooperation for schools, businesses and students is a "three hands win-win" model. In addition, basing on these platforms the school can also set up a variety of innovative business associations, business clubs and other societies hold a variety of innovative business seminars forum, to carry out various types of college students' innovation and entrepreneurship competition, technological innovation, creative design, business plans and other thematic competition. The government needs to provide college students with a variety of preferential business space and provide innovative business incentives. Enterprises should bear social responsibility for higher vocational students to provide more cooperation platform and entrepreneurial opportunities.

Change the innovation and entrepreneurship education and evaluation methods basing on school-enterprise cooperation. To build a "competency-based" assessment methods for innovation and entrepreneurship education with enterprises and to abandon the traditional spoon-fed education model under the simple test paper examination mode. Innovation and entrepreneurship education pays attention to the cultivation of students' innovative and enterprising consciousness, cultivating innovative and practical ability. The focus of the assessment should be on the evaluation of students' innovation and entrepreneurship awareness and the innovation and practice ability. And this 
assessment content can be conducted through the judge of the students' daily use of professional knowledge, the problem solving of the innovation and entrepreneurship problems. The teachers also can assess students from their specific innovation and entrepreneurship practices, such as to carry out entrepreneurial activities independently, to obtain innovative business competition awards. If they can achieve good results in the innovation and entrepreneurship competition, they are excellent in the innovation and entrepreneurship education. Conducting this assessment requires the participation of enterprises in the assessment.

Cultivating strong innovation and entrepreneurship campus culture atmosphere basing on school-enterprise cooperation. Each college has a distinctive character, and this trait also deeply affects the quality of students and the characteristics of students. If the vocational colleges cultivate a strong atmosphere of innovation and entrepreneurship culture and the formation of a unique cultural heritage, beliefs, quality and value orientation, and let students be influenced at all times in this cultural atmosphere in the three years of vocational education, then the students will naturally form innovative business awareness and ability. The path of cultivating this campus culture is mainly in the following areas. Firstly, the colleges need to integrate the concept of innovation and entrepreneurship into the school motto, and promote the spirit of innovation and entrepreneurship as one of the school's education behavior, and then integrate this spirit into the whole process of talent training, to cultivate students' entrepreneurship spirit and pioneering spirit. Second, colleges need to establish a core innovation and entrepreneurship culture brand, such as the establishment of innovative business series of brand activities, inviting innovative entrepreneur's alumni, entrepreneurs for students to teach entrepreneurship, to give lectures about small and medium-sized, micro-enterprise development ideas, technology trends, innovation and entrepreneurship experience, business management and other topics. Students have the opportunity to gain a deep understanding of entrepreneurial knowledge, prepare for projects and teams to improve project feasibility. Through inviting the relevant government officials to convey policies, answer questions and provide directions, to make students know the actual policies of the county about the innovation and entrepreneurship. Third, colleges can make innovation and entrepreneurship orientation policies to encourage the students. The college can make rules and regulations to encourage students to attend different innovation and entrepreneurship competitions and activities, if they can get awards or can set up actual running businesses, they can get credit points. Schools can also set up innovation and entrepreneurship scholarships with enterprises for college students to encourage them. Schools also can make flexible credit system for students, such as allowing students to stop to do innovation and entrepreneurship activates, allowing students to work half-time to start business and so on.

\section{Conclusions}

Innovation and entrepreneurship education in higher vocational education needs enterprise's deep participation. The main modes for enterprises to participate in innovation and entrepreneurship education are participation in the education steering committee, order classes, teacher exchanges, to provide internship positions and build cooperative enterprises. The innovation and entrepreneurship education of higher vocational students needs to be integrated into the personnel training mode, the talent quality standard, the curriculum system construction, the ability appraisal and the campus culture all aspects of practical activities.

\section{Acknowledgements}

This paper is one of research achievements of the project of "Study on innovation and entrepreneurship model and practice of specialty of business management basing on the cooperation between colleges and companies" which is financially supported by the "Higher education teaching reform and research project of Chongqing Education Commission of 2016”. (Project Number: 163233. Leading researcher: Yuzhong Sun.) 


\section{References}

[1] Z.C.Zhou:Journal of Beijing Jiaotong University(Social Sciences Edition, （2011）.No.13,p.123. (In Chinese)

[2] Y.J.Wu: Education Exploration, （2015）.No.11, p.63. (In Chinese)

[3] B.Zhang and H.Bai: Higher Education Exploration, （2014）.No.3, p.51. (In Chinese) 